\title{
Draft of strategy of the European rail freight corridor Amber
}

\author{
Juraj Kanis ${ }^{1}$, Anna Dolinayova ${ }^{2 *}$ and Matej Kmetik $^{3}$ \\ ${ }^{1}$ VVUŽ Žilina, Section of Expert Activities, 01002 Žilina, Slovakia \\ ${ }^{2}$ University of Žilina, Faculty of Operation and Economics of Transport and Communications, 01026 Žilina, Slovakia \\ 3University of Pardubice, Faculty of Transport Engineering, 53210 Pardubice, Czech Republic
}

\begin{abstract}
An increase in rail freight transport performances is affected by the quality of transport services, which is influenced to the great extent by the transport infrastructure and infrastructure manager services. An increase in the quality of services provided by railway infrastructure has also been achieved through the establishment of the European rail freight corridors. At the same time, the trends in routing of goods flows and demand for transport services have contributed to the establishment of the new European rail freight corridor "Amber". For this reason, an implementation strategy of the Amber corridor is proposed using the SWOT method and Balanced Score Card method. The draft of strategy is based on the findings contained in the study of transport and market environment of the Amber corridor.
\end{abstract}

\section{Introduction}

The current economic development in EU countries has an impact on continuous increase in demand for transport services. The continuous increase in demand for transport services results from a higher consumption of EU population and a higher production manufacturing enterprises. The demand is directly influencing also by the need to transport, the final products and the intermediate products from East Europe and Asia [1]. Several European companies cooperate with the companies in Asia and their income, level of innovations and social benefits depend on their cooperation. This demand then creates an offer that results in a market for transport services. There are many offers from several modes of transport in this market, where each mode of transport has its advantages and disadvantages for the transport process, the society and environment [2].

Rail freight is currently considered to be the most environmentally friendly mode of transport of goods, with an important role in the freight transport market. It contributes to the development of human society and combines economic and social progress while respecting the development [3]. Due to exogenous (e.g. entry of competition in road and air transport, technological innovations oriented to other modes of transport, change in transport requirements) and endogenous (e.g. inefficiency, overemployment, low level of innovations and modernization, technological lag) factors, rail freight lost the competitiveness in the transport services market resulting in decrease in the transport performances of rail sector [4]. At the same time a shift of transport performances to other more environmentally demanding modes of transport has occurred. This shift leads to a higher production of the negative external costs of transport and need for higher state subsidies to the transport from public funds. This unfavorable condition has to be addressed by individual states and EU.

EU, to promote the competitiveness of rail freight transport, in particular in the field of infrastructure quality, safety, time and administrative effectiveness, international cooperation, has established the European Rail Freight Corridors [5]. The establishment of the European Rail Freight Corridors should bring, in particular, better, more complete, more reliable and less expensive services to railway undertakings. Such services of the single European railway infrastructure consequently contribute to the better services of the railway undertakings providing freight services [6]. Increased commercial activity, reliable, fast and safe and cost competitive service lead to a shift of transport performances from more environmentally demanding modes of transport to rail freight transport. In addition to its environmental advantage, rail freight transport can provide more reliable, safer, less expensive and faster transport service in case of harmonizing the transport and technological processes in comparison with other modes of transport [7]. The shift of transport performances to rail leads to overall decrease in social costs (infrastructure owner costs, carrier costs and negative external costs of transport) generated by transport. Increasing requirements on quality and availability of rail freight service led to intention to establish the new European rail freight corridor Amber. The corridor establishment brings the connection between Adriatic seaports in the Republic of Slovenia and inland ports on the Danube and terminals in Hungary and the Slovak Republic and Poland, but it brings also the perspective of railway transport development with Serbia and the improvement of the railway transport in Europe - Asia direction. The Amber RFC implementation plan requires a draft of strategy.

* Corresponding author: anna.dolinayova@,fpedas.uniza.sk 
For this reason, we decided to propose a strategy for Amber RFC, in this paper. The proposed strategy is developed based on the technical and technological statistical data provided by the affected infrastructure managers using the synthetic SWOT analysis method and the Balanced scorecard method.

\section{Aspects of establishing the Amber RFC}

The main objectives of establishing the rail freight corridors, defined by the European Commission (hereinafter referred to as EC) are:

- Strengthening competitiveness of rail freight transport compared with other modes of transport,

- Effective modal split with an emphasis on environmentally friendly rail freight transport,

- Coordination of investment in more qualitative railway infrastructure with possibility of financial support from EU funds,

- Harmonization and synergy between national rail systems,

- Strengthening cooperation in allocation of railway infrastructure capacity to international freight trains between single infrastructure managers,

- Conformity with existing objectives of other specific freight corridors [8].

The establishment of the Amber RFC is to lead to the fulfilment of the partial objectives that can be summarized in the following points:

- General growth of transit rail freight performances,

- General growth of international rail freight performances,

- General growth of intermodal transport performances.

- Improve the interconnection of the main intermodal transport terminals,

- Facilitate the interconnection between the Adriatic Sea Port in the Republic of Slovenia and the inland ports on the Danube in Hungary and the Slovak Republic,

- Promote the railway transport development with Serbia,

- Improve, potentially, the railway transport across EU Eastern border and on the land bridge between Europe and Asia,

- Better services of infrastructure managers provided to railway undertakings,

- Better services provided by railway undertakings to customers,

- Shift of transport performances from environmentally demanding modes to rail freight - change in modal split in favour of rail freight,

- Increase in reliability and decrease in transport time,

- Decrease in railway undertaking costs,

- Growth of socio-economic efficiency of the railway system [9].

In addition to the partial objectives mentioned above, the establishment of the Amber RFC also brings particular benefits to railway undertakings and terminals:

- Participation in the process of creating a corridor offer,

- Overview concerning the capacity included in the corridor, including the capacity provided with priority,
- Better services in terms of transit time, regularity, reliability and information,

- Strengthening customer approach,

- Information on investment projects in railway infrastructure between railway administrations,

- Information about operating restriction,

- Harmonization of infrastructure technical transport parameters,

- Harmonization of track possessions between individual railway infrastructure managers,

- Better possibility to improve the infrastructure included in the corridor,

- Support for remove of technical and technological barriers,

- Chance to strengthen priority rules in operative traffic control for freight trains carrying out transport performances on the corridor,

- Possibility to express the opinion of carriers on the quality of Amber corridor services.

The defined objectives and benefits of the Amber RFC establishment are, in particular, to increase the competitiveness of rail freight services compared with other modes of freight transport. The expected objectives and benefits are to contribute to better, more reliable and more available rail freight services and harmonization technological and operational conditions. The fulfilment of Amber corridor's objectives requires the cooperation of all stakeholders: state, government, ministries concerned, infrastructure managers, carriers, intermodal operators and external suppliers of the railway sector.

\section{Characteristics of Amber RFC}

The Amber rail freight corridor No 11 is being established based on Commission Implementing Decision (EU) no. 2017/177 of 31 January 2017, that was issued of the basis of "Letter of intent" as request of 4 Ministries competent for Rail Transport of Hungary, Republic of Poland, Slovak Republic and Republic of Slovenia. The establishment of Amber rail freight corridor is on the compliance with Article 5 of Regulation (EU) No 913/2010 of the European Parliament and of the Council of 22 September 2010 concerning a European rail network for competitive freight. This Regulation lays down rules for the establishment and organization of international rail freight corridors with a view to the development of a European rail network for competitive freight [8], [9].

RFC Amber routing: Koper-Ljubljana/Zalaszentivan -Sopron/Csorna/(Hungarian/Serbian border) - Kelebia Budapest- Komárom- Leopoldov/Rajka -BratislavaŽilina-Katowice/Kraków-Warszawa/Łuków - Terespol - (Polish/Belorusian border) [9].

Member states: Republic of Poland, Slovak Republic, Hungary, Republic of Slovenia.

Length of railway lines: approximately $3400 \mathrm{~km}$.

Seaports: 1

Inland ports: 3

Intermodal transport terminals: 25

Deadline for making Amber RFC operational: by 30.01.2019 
Seat of Corridor One Stop Shop (C-OSS): Poland Equations should be centred and should be numbered with the number on the right-hand side.

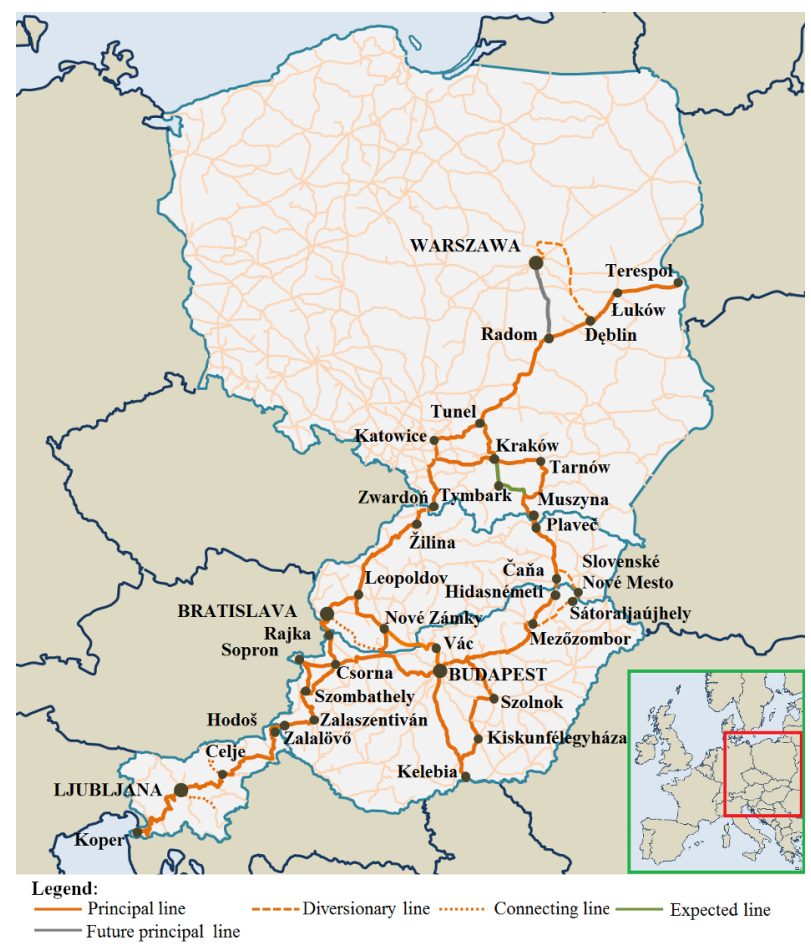

Fig. 1. Graphical representation of Amber RFC routing

\section{Draft of the Amber corridor strategy}

We suggested the Amber corridor strategy using two methods: SWOT analysis and Balanced Scorecard method. Draft takes into account comments and suggestions Infrastructure managers of MAV, GYSEV, VPE, SŽ-I and PKP.

\subsection{SWOT analysis}

Method of SWOT analysis consists in identifying the internal environment of the studied subject using its strengths and weakness and in identifying the impact of external environment using opportunities and threats. Based on recognized results a review of internal and external environment analysis will be obtained, while the most appropriate strategy for the studied subject will be made up based on given scores. Elaboration SWOT analysis is conditioned by completion of collection and subsequent evaluation of all available data collected. Then, the created basis of SWOT analysis is qualitatively and quantitatively assessed by independent experts and stakeholders, in this case by individual members of Amber RFC. Without assessment of several experts and stakeholders [10], SWOT analysis has only subjective character of its maker and it is inconsistent for the adoption of strategic direction and decision-making.

\section{Strengths and weakness:}

- Importance. Importance shows how important or a weakness is for organization as some strengths (weakness) might be more important than others might.
A number from 0,01 (not important) to 0,99 (very important). The sum of all weights should equal 1,0.

- Rating. A score from 1 to 6 is given to each factor to indicate whether it is a major (6) or a minor (1) strength for the organization. The same rating should be assigned to the weaknesses where -1 would mean a minor weakness and -6 major weakness.

- Score. Score is result of importance multiplied by rating. It allows prioritizing the strengths and weakness. You should rely on your most important strengths and try to convert or defend your weakest parts of the organization.

\section{Opportunities and threats:}

- Importance. It shows to what extent the external factor might influence the business. Again, the numbers from 0,01 (no impact to 0,99 (very high impact) should be assigned to each item. The sum of all weights should equal 1,0 .

- Probability. Probability of occurrence is showing how likely the opportunity or threat will have any impact on business. It should be rated from 1 (low probability) to 6 (high probability). For threats -1 (low probability) to -6 (high probability).

- Score. Importance multiplied by probability will give a score by which you'll be able to prioritize opportunities and threats. Pay attention to the factors having the highest score and ignore the factors that will not likely affect your business.

The following four tables give strength, weaknesses, opportunities and threats of internal and external environment of Amber RFC [12, 13].

Table 1. Strengths of Amber RFC

\begin{tabular}{|l|c|c|c|}
\hline S (Strengths) & $\begin{array}{c}\text { Impor- } \\
\text { tance }\end{array}$ & $\begin{array}{c}\text { Ra- } \\
\text { ting }\end{array}$ & Score \\
\hline $\begin{array}{l}\text { Interconnection of railway infrastructure } \\
\text { within the countries included in Amber } \\
\text { RFC }\end{array}$ & 0,07 & 5 & 0,35 \\
\hline Railway system reliability & 0,08 & 5 & 0,41 \\
\hline $\begin{array}{l}\text { Available information on technical } \\
\text { specification of corridor railway lines }\end{array}$ & 0,04 & 5 & 0,18 \\
\hline $\begin{array}{l}\text { Access to the important seaport Koper in } \\
\text { the Republic of Slovenia }\end{array}$ & 0,10 & 5 & 0,51 \\
\hline $\begin{array}{l}\text { Thanks to the corridor strategic location } \\
\text { and routing, good connection with other } \\
\text { RFC corridors is guaranteed }\end{array}$ & 0,08 & 5 & 0,41 \\
\hline $\begin{array}{l}\text { Existing cooperation between individual } \\
\text { infrastructure managers within Amber } \\
\text { RFC countries }\end{array}$ & 0,08 & 5 & 0,40 \\
\hline Railway infrastructure safety & 0,10 & 6 & 0,54 \\
\hline $\begin{array}{l}\text { Good technical conditions of railway } \\
\text { infrastructure }\end{array}$ & 0,08 & 5 & 0,41 \\
\hline Available free capacity & 0,07 & 5 & 0,39 \\
\hline $\begin{array}{l}\text { Connection by rail with countries outside } \\
\text { the EU through BY/PL (Brest/Terespol) } \\
\text { railway border crossing }\end{array}$ & 0,10 & 6 & 0,60 \\
\hline $\begin{array}{l}\text { Flexibility of railway infrastructure (e.g. } \\
\text { suitable alternative routes) }\end{array}$ & 0,05 & 6 & 0,28 \\
\hline Schengen area & 0,03 & 6 & 0,21 \\
\hline $\begin{array}{l}\text { Procurement of railway infrastructure } \\
\text { capacity from one place C-OSS }\end{array}$ & 0,05 & 4 & 0,19 \\
\hline $\begin{array}{l}\text { Connection of railway transport with } \\
\text { terminals within Amber RFC }\end{array}$ & 0,06 & 5 & 0,31 \\
\hline TOTAL & $\mathbf{1}$ & - & $\mathbf{5 , 1 9}$ \\
\hline
\end{tabular}


In tables, there are assigned importance to each indicator and scores achieved. These two figures are then multiplied, while their product determines the final evaluation of indicator. [14] The data presented in the tables are the resulting average values obtained from the infrastructure managers affected by the Amber RFC, the TMS elaborator and the academic environment.

Table 2. Weaknesses of Amber RFC

\begin{tabular}{|l|c|c|c|}
\hline W (Weaknesses) & $\begin{array}{c}\text { Impor- } \\
\text { tance }\end{array}$ & $\begin{array}{c}\text { Ra- } \\
\text { ting }\end{array}$ & Score \\
\hline $\begin{array}{l}\text { Insufficient implementation of TEN-T } \\
\text { infrastructure minimum standards }\end{array}$ & 0,09 & -4 & $-0,38$ \\
\hline $\begin{array}{l}\text { Enforcement of various interests of } \\
\text { infrastructure managers of member } \\
\text { states }\end{array}$ & 0,12 & -3 & $-0,34$ \\
\hline $\begin{array}{l}\text { Traffic restrictions related to } \\
\text { possession causing temporary capacity } \\
\text { constraint }\end{array}$ & 0,17 & -5 & $-0,78$ \\
\hline $\begin{array}{l}\text { Reducing the quality of rail freight } \\
\text { services provided within Amber RFC }\end{array}$ & 0,14 & -3 & $-0,42$ \\
\hline $\begin{array}{l}\text { Poor technical condition in some } \\
\text { sections of railway lines }\end{array}$ & 0,15 & -5 & $-0,69$ \\
\hline Bottlenecks of capacity utilization & 0,10 & -5 & $-0,44$ \\
\hline $\begin{array}{l}\text { Insufficient technical parameters of } \\
\text { railway infrastructure - requirements } \\
\text { for modernization }\end{array}$ & 0,11 & -5 & $-0,57$ \\
\hline Long waiting times at border crossings & 0,13 & -4 & $-0,50$ \\
\hline TOTAL & $\mathbf{1}$ & - & $\mathbf{- 4 , 1 1}$ \\
\hline
\end{tabular}

Table 3. Opportunities of Amber RFC

\begin{tabular}{|l|c|c|c|}
\hline O (Opportunities) & $\begin{array}{c}\text { Impor- } \\
\text { tance }\end{array}$ & $\begin{array}{c}\text { Ra- } \\
\text { ting }\end{array}$ & $\begin{array}{c}\text { Sco- } \\
\text { re }\end{array}$ \\
\hline $\begin{array}{l}\text { Trend of using more environmentally } \\
\text { friendly mode of transport } \\
\text { (opportunity for rail transport) }\end{array}$ & 0,08 & 4 & 0,35 \\
\hline $\begin{array}{l}\text { Complete modernization of railway } \\
\text { lines which limit the increase of line } \\
\text { capacity }\end{array}$ & 0,12 & 4 & 0,51 \\
\hline $\begin{array}{l}\text { Investment of railway undertakings } \\
\text { in sidings and siding operation }\end{array}$ & 0,08 & 4 & 0,34 \\
\hline $\begin{array}{l}\text { Increase in costs of road goods } \\
\text { transport, e.g. toll charges }\end{array}$ & 0,10 & 5 & 0,47 \\
\hline $\begin{array}{l}\text { Increase in impact of transport policy } \\
\text { of individual countries in favour of } \\
\text { rail }\end{array}$ & 0,10 & 5 & 0,47 \\
\hline $\begin{array}{l}\text { Favourable economic growth of } \\
\text { countries included in Amber RFC } \\
\text { resulting in increase of import / } \\
\text { export }\end{array}$ & 0,12 & 5 & 0,56 \\
\hline $\begin{array}{l}\text { Improving mutual cooperation } \\
\text { between RFC corridors }\end{array}$ & 0,06 & 5 & 0,30 \\
\hline $\begin{array}{l}\text { Potential for corridor extension to } \\
\text { the north of the Republic of Poland } \\
\text { towards seaports }\end{array}$ & 0,08 & 4 & 0,32 \\
\hline $\begin{array}{l}\text { Connection of major economic } \\
\text { active regions within the Amber } \\
\text { RFC }\end{array}$ & 0,09 & 4 & 0,38 \\
\hline $\begin{array}{l}\text { Investment and modernization (e.g. } \\
\text { construction of new line, double- } \\
\text { tracking, station upgrade-signalling } \\
\text { equipment, etc.) }\end{array}$ & 0,08 & 3 & 0,23 \\
\hline $\begin{array}{l}\text { Connection between inland ports on } \\
\text { the Danube in Hungary and Slovakia }\end{array}$ & 0,05 & 4 & 0,21 \\
\hline $\begin{array}{l}\text { Connection with the lines in the } \\
\text { Czech Republic }\end{array}$ & 0,03 & 5 & 0,17 \\
\hline TOTAL & $\mathbf{1}$ & - & $\mathbf{4 , 3 2}$ \\
\hline
\end{tabular}

Table 4. Threats of Amber RFC

\begin{tabular}{|l|c|c|c|}
\hline T (Threats) & $\begin{array}{c}\text { Impor- } \\
\text { tance }\end{array}$ & $\begin{array}{c}\text { Ra- } \\
\text { ting }\end{array}$ & Score \\
\hline $\begin{array}{l}\text { Building logistic centres without } \\
\text { connection to railway infrastructure }\end{array}$ & 0,06 & -3 & $-0,17$ \\
\hline Lack of qualified personnel in operation & 0,08 & -4 & $-0,37$ \\
\hline $\begin{array}{l}\text { Insufficient coordination in infrastructure } \\
\text { development work }\end{array}$ & 0,09 & -4 & $-0,37$ \\
\hline $\begin{array}{l}\text { Reducing transport volumes of } \\
\text { international freight trains }\end{array}$ & 0,10 & -4 & $-0,34$ \\
\hline $\begin{array}{l}\text { Tendency of transport policy of } \\
\text { individual countries to rail transport } \\
\text { disadvantage }\end{array}$ & 0,06 & -3 & $-0,16$ \\
\hline $\begin{array}{l}\text { Unfavourable economic development } \\
\text { within Amber RFC countries }\end{array}$ & 0,07 & -3 & $-0,21$ \\
\hline $\begin{array}{l}\text { Reducing investment subsidies for rail } \\
\text { transport }\end{array}$ & 0,07 & -4 & $-0,30$ \\
\hline $\begin{array}{l}\text { Reducing non-investment subsidies for } \\
\text { rail transport }\end{array}$ & 0,06 & -3 & $-0,19$ \\
\hline $\begin{array}{l}\text { Higher transport time compared to road } \\
\text { goods transport }\end{array}$ & 0,10 & -5 & $-0,44$ \\
\hline $\begin{array}{l}\text { Lower flexibility compared to road } \\
\text { goods transport }\end{array}$ & 0,10 & -5 & $-0,46$ \\
\hline $\begin{array}{l}\text { Insufficient coverage of railway corridor } \\
\text { routes to cover customer needs }\end{array}$ & 0,11 & -5 & $-0,57$ \\
\hline $\begin{array}{l}\text { Stagnation (unsolved problems) in the } \\
\text { field of maintenance and modernization }\end{array}$ & 0,10 & -2 & $-0,25$ \\
\hline TOTAL & $\mathbf{1}$ & - & $\mathbf{- 3 , 8 2}$ \\
\hline
\end{tabular}

The quantitative scores were assigned to strengths, weaknesses, opportunities and threats (risks) in SWOT analysis for the Amber RFC. Quantified assessment of internal and external environment analysis needs to be put in comparison of vectors from which we find a particular position, which represents model strategy for the Amber RFC.

Using quantified evaluation of internal and external environment, it was found by comparison of vectors: Offensive strategy, as model strategy for the Amber RFC. Graphical representation of matrix of model strategies with initial strategy for the Amber RFC is shown in Figure 2.

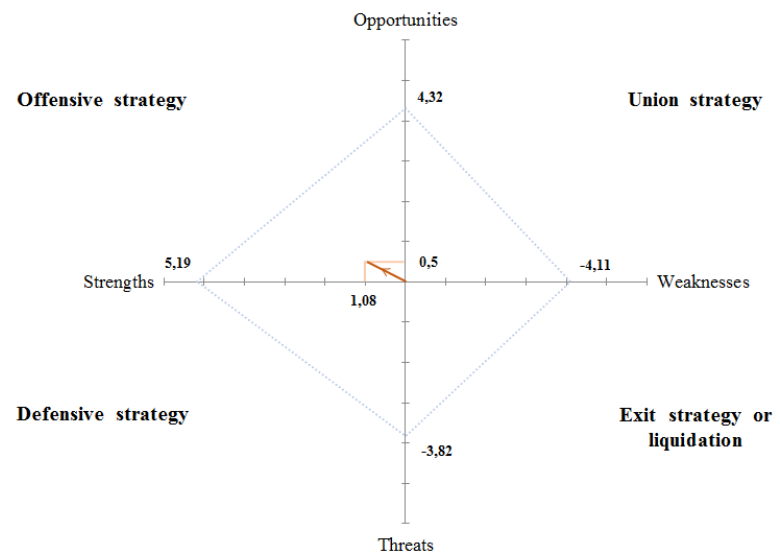

Fig..2. Matrix of model strategies for the Amber RFC

Offensive strategy is considered the most attractive strategic alternative. It can be used by an entity whose position is ideal with the predominant strengths over the weaknesses. Such an entity is able to use its strengths to realize the opportunities offered by the external environment. [15] However, an entity must monitor its 
weakness and avoid defined risks. Based on the resultant strategy, it is necessary to take the following measures for the Amber RFC:

- Increase the reliability of rail system services,

- Developing the high-quality and available services of C-OSS

- Developing the cooperation with other RFC corridors,

- Support for intermodal transport services,

- Reducing the railway infrastructure charges for local service trains- positive impact on last mile,

- In operative transport management, to proceed to prioritize international freight trains,

- Cooperation with seaport and inland port Małaszewicz,

- Close cooperation between infrastructure managers,

- Coordination of investment projects in railway infrastructure within Amber RFC lines,

- Increased awareness of the corridor, its services and perspectives,

- Exchange of information concerning operation, control and possessions,

- Measures to reduce the technological times of operations for transport of goods from/to countries outside the EU,

- Providing the best resource, e.g. human, IT,

- Investments in interoperability,

- Exclusive or dominant access to the most capable suppliers of MB Amber RFC.

These measures result from the strategy and its characteristics. However, the Amber corridor bodies cannot affect all measures. Therefore, it is necessary that the subjects that can influence the individual measures proceed to their implementation, thereby helping to meet the expected goals and benefits of the Amber corridor establishment.

\subsection{Balanced Scorecard Method}

In order to fulfil the basic objectives of the Amber RFC, it is necessary to set out the strategic steps for their fulfilment. One of the appropriate methods for creating strategic processes is the Balanced Score Card - BSC. BSC is complex strategic method that looks at the subject under consideration through four perspectives and their mutual relationships. I tis a financial, customer, process, learning and growth perspective. BSC is based on the vision and strategy of the object under consideration and on that basis for each perspective the mission and strategic objectives, to which certain metrics and their target values are assigned, will be determined. All perspectives are logically connected and linked and this method, therefore, provides a complex view of the object under consideration and its performance [16].

\section{Amber RFC main vision are:}

- Growth of rail freight transport performance,

- Fulfilling the EU transport objectives and reducing the negative external costs of transport,

- Strengthening rail freight position within the individual member states of the Amber RFC,

- Expand cooperation with rail carriers as well as between IM,

- Strengthening and developing the cooperation between RFC corridors,

- Maintaining and developing the rail freight services,

- Developing the services concerning free capacity allocation,

- Fulfilling the basic objectives of the liberalization of rail freight services market [12].

Amber RFC mission consists particularly in:

- Providing and improving the rail freight services,

- Creating a positive perception of rail freight transport and the Amber RFC,

- Development and modernization of railway infrastructure,

- Participation in transport policy development within the individual countries of the Amber RFC as well as at the EU level,

- Promoting the development of rail freight transport as an environmentally friendly and perspective mode of transport compared to road transport,

- Decreasing the transport performances of more environmentally demanding modes of transport,

- Available non-discriminatory access to railway infrastructure and its capacity,

- Effective transport of goods from/to EU, from/to countries outside the EU,

- Reducing public spending,

- High satisfaction of all customers of the Amber RFC [16].

Figure 3 shows the BSC strategic map for Amber corridor. The strategic map is based on the vision and mission of the Amber RFC and its four perspectives.

\section{Conclusion}

The paper deals with the draft of the Amber corridor strategy. The draft of strategy itself was created using the data and results included in the study of transport and market environment of the Amber corridor elaborated by the Research and Development Institute of Railways Žilina. The strategy is to serve for the implementation plan, support of management and routing of the corridor so that it provides high-quality and available services. The high-quality services should lead to an efficient modal split in the freight transport and so to promote sustainable development.

The paper was supported by the project EUREKA E!11214 EPLOS - "European portal of logistics services" at Faculty of Operations and Economics of Transport and Communication, University of Žilina, Slovakia.

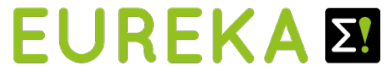

innovation across borders

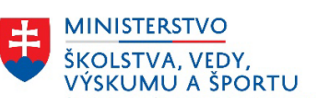
VYSKUMU A ŠPORTU SLOVENSKE] REPUBLIKY 


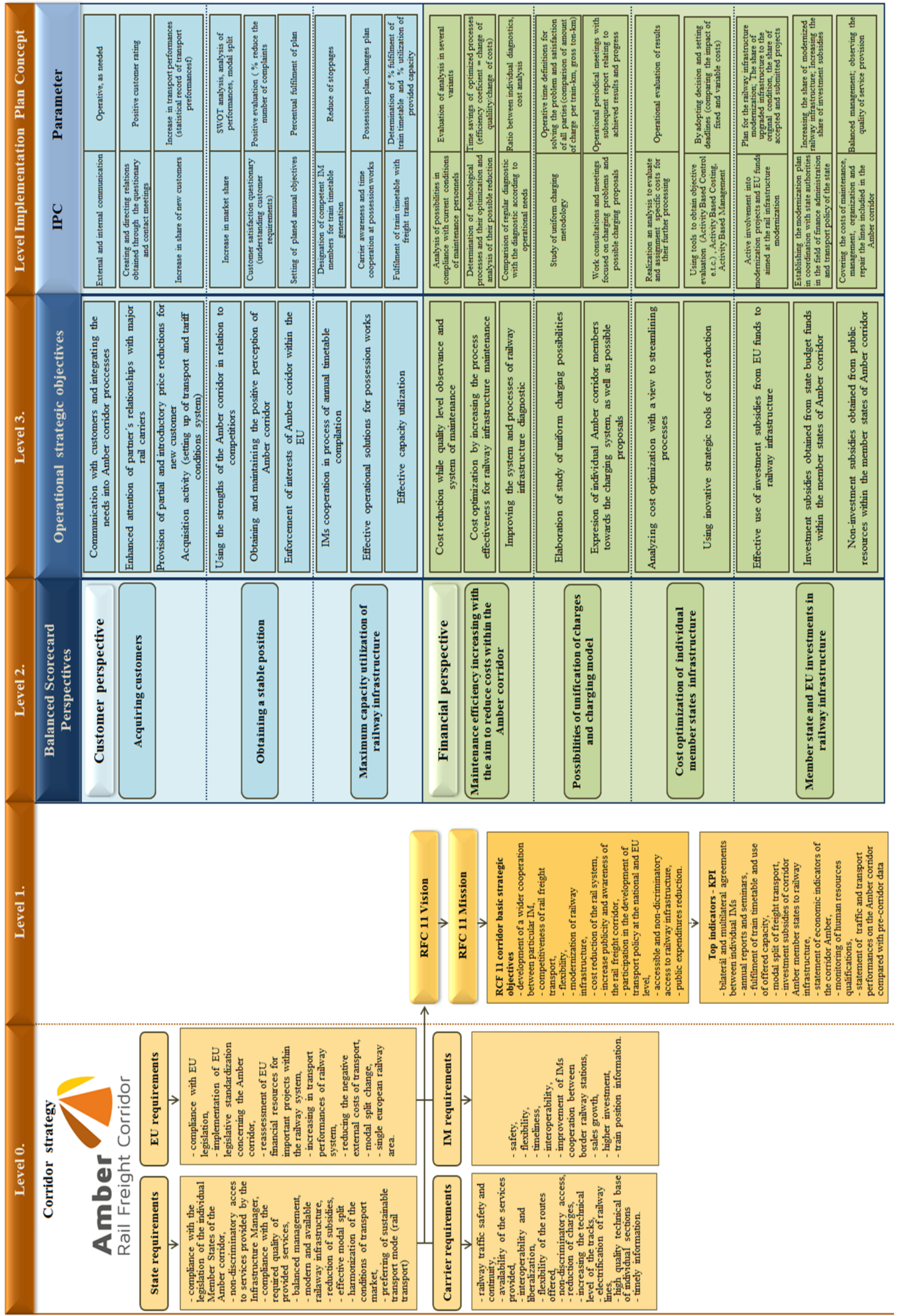

Fig. 3. Map Balanced Score Card of Amber RFC

\footnotetext{
*Corresponding author: anna.dolinayova@,fpedas.uniza.sk
} 


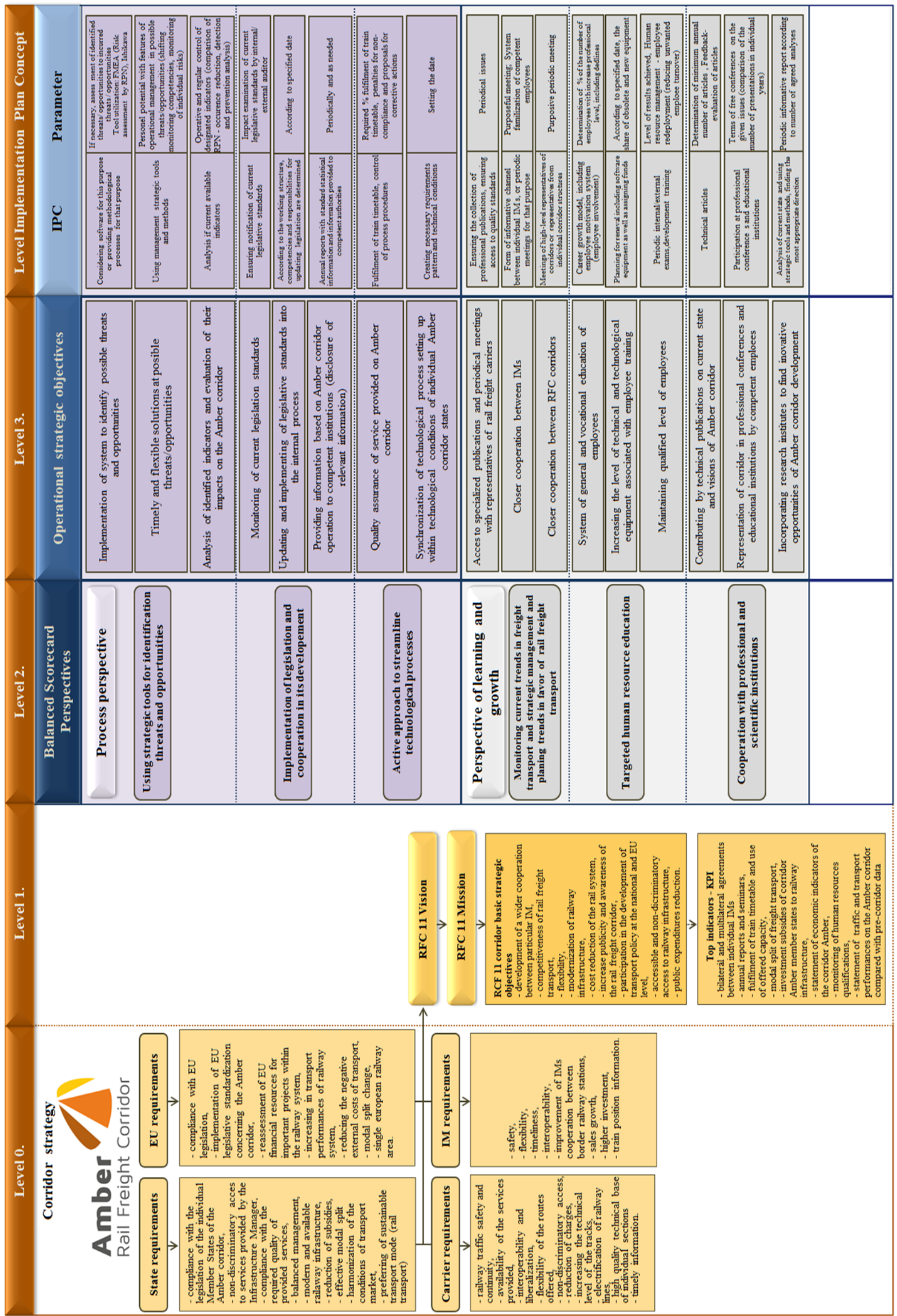

Fig. 3. Map Balanced Score Card of Amber RFC - Continue 


\section{References}

1. P. Drozdiel, B. Bukova, E. Brumercikova, Transport Problems 10, 4 (2015)

2. T. Skrucany, M. Kendra, B. Sarkan, J. Gnap, Communications in Computer and Information Science, 531 (2015)

3. P. Mesko, J. Gasparik, V. Gaborova, Proceedings of the 20th International Scientific Conference Transport Means (2016)

4. T. Zunder, DMZ Islam, M. Marinov, Transport problems, 5, 3 (2010)

5. M. Poliak. EKONOMICKY CASOPIS. 61, 2. 206220. (2013)

6. V. Zitrický, L. Černá, B. Abramovič, Procedia Engineering, 192 (2017)

7. O. Stopka, R. Kampf. Transport, 33, 280-290. (2018) DOI: $10.3846 / 16484142.2016 .1174882$.

8. B. Abramovic, E. Nedeliakova, M. Panak, D. Sipus. Proceedings of International Scientific Conference Business Logistics in Modern Management (2017)

9. E. Nedeliakova, M. Panak, J. Ponický, R. Soušek. AER - Advances in Engineering Research. 62, 195198. (2016)
10. R. Kampf, L. Lizbetinova, K. Tislerova, Open Engineering, 7, 1 (2017)

11. Regulation (EU) No $913 / 2010$ of the European Parliament and of the Council of 22 September 2010 concerning a European rail network for competitive freight. Available at: https:/eur-lex.europa.eu/ LexUriServ/LexUriServ.do?uri=OJ:L:2010:276:0022 :0032:EN:PDF

12. M. Kvizda, Politická ekonomie. 53. 5. 617-633. (2005)

13. Commission Implementing Decision (EU) 2017/177 of 31 January 2017 on the compliance with Article 5 of Regulation (EU) No 913/2010 of the European Parliament and of the Council of the joint proposal to establish the 'Amber' rail freight corridor. Available at: https://eur-lex.europa.eu/legal-content/EN/TXT/ ?uri $=$ CELEX\%3A32017D0177

14. A. Galierikova, J. Sosedova, NASE MORE. 65, 3. $8-11.2018$

15. A. Torok. Procedia Engineering 187, 722-725, (2017), https://doi.org/10.1016/j.proeng.2017.04.446

16. Š. Zapletalová. Business Environment. [In Czech: Podnikatelské prostředí], (Slezská univerzita, 2016)

17. The study of TMS Corridor Amber, VVUŽ Žilina. Internal material (2018)

*Corresponding author: anna.dolinayova@fpedas.uniza.sk 